\title{
Potential Activity of Subglacial Microbiota Transported to Anoxic River Delta Sediments
}

\author{
Karen A. Cameron ${ }^{1,2,3} \cdot$ Marek Stibal $^{1,2,4}$ • Nikoline S. Olsen ${ }^{1,2} \cdot$ Andreas B. Mikkelsen $^{2}$ • \\ Bo Elberling ${ }^{2}$ - Carsten S. Jacobsen ${ }^{1,2,5}$
}

Received: 19 September 2016 / Accepted: 26 December 2016/Published online: 9 January 2017

(C) The Author(s) 2017. This article is published with open access at Springerlink.com

\begin{abstract}
The Watson River drains a portion of the SW Greenland ice sheet, transporting microbial communities from subglacial environments to a delta at the head of Søndre Strømfjord. This study investigates the potential activity and community shifts of glacial microbiota deposited and buried under layers of sediments within the river delta. A long-term (12-month) incubation experiment was established using Watson River delta sediment under anaerobic conditions, with and without $\mathrm{CO}_{2} / \mathrm{H}_{2}$ enrichment. Within $\mathrm{CO}_{2} / \mathrm{H}_{2}$-amended incubations, sulphate depletion and a shift in the microbial community to a $52 \%$ predominance of Desulfosporosinus meridiei by day 371 provides evidence for sulphate reduction. We found evidence of methanogenesis in $\mathrm{CO}_{2} / \mathrm{H}_{2}$-amended
\end{abstract}

Amplicon data sets are available at The European Bioinformatics Institute under study accession number PRJEB14184.

Electronic supplementary material The online version of this article (doi:10.1007/s00248-016-0926-2) contains supplementary material, which is available to authorized users.

Karen A. Cameron

kac.geus@gmail.com

1 Department of Geochemistry, Geological Survey of Denmark and Greenland (GEUS), Øster Voldgade 10,

DK-1350 Copenhagen, Denmark

2 Center for Permafrost (CENPERM), University of Copenhagen, Øster Voldgade 10, DK-1350 Copenhagen, Denmark

3 Institute of Biological, Environmental and Rural Sciences (IBERS), Aberystwyth University, Penglais, Aberystwyth SY23 3FL, UK

4 Department of Ecology, Faculty of Science, Charles University, Viničná 7, 12843 Prague, Czech Republic

5 Department of Environmental Science, Aarhus University, Frederiksborgvej 399, DK-4000 Roskilde, Denmark incubations within the first 5 months, with production rates of $\sim 4 \mathrm{pmol} \mathrm{g}^{-1} \mathrm{~d}^{-1}$, which was likely performed by methanogenic Methanomicrobiales- and Methanosarcinales-related organisms. Later, a reduction in methane was observed to be paired with the depletion of sulphate, and we hypothesise that sulphate reduction out competed hydrogenotrophic methanogenesis. The structure and diversity of the original $\mathrm{CO}_{2} / \mathrm{H}_{2}$-amended incubation communities changed dramatically with a major shift in predominant community members and a decline in diversity and cell abundance. These results highlight the need for further investigations into the fate of subglacial microbiota within downstream environments.

Keywords Subglacial environment $\cdot$ River delta $\cdot$ Sulphate reduction $\cdot$ Methanogenesis $\cdot$ Meltwater export $\cdot$ Methane oxidation

Greenland has been estimated to contribute towards $\sim 7 \%$ of the world's suspended sediment flux [1]. At Leverett Glacier, in the southwest of the Greenland Ice Sheet (GrIS), approximately $10^{11}$ microbial cells per cubic meter of meltwater are exported alongside these sediments [2]. These cells and sediments are mostly sourced from the subglacial environment [1, 2], and the Watson River channels them to the downstream fjord with minimal changes to their community composition [2]. Under the assumption that cells are deposited alongside glacial sediments in the river delta at the fjord head, which likely amass at rates of 9 $16 \mathrm{~mm} \mathrm{yr}^{-1}$ [1], and assuming that once buried under subsequent depositions the environment becomes waterlogged and anoxic, this study sought to consider the potential activity of transported subglacial communities, especially methanogens, whose potential activity and greenhouse gas production has been reported previously [3-8]. We hypothesised that subglacial methanogens resume their activity after deposition within anoxic sediments. 
To test our hypothesis, we established long-term (12-month) anaerobic incubations using sediment core material sampled from the Watson River delta at the head of Søndre Strømfjord, where the meltwaters of four southwest GrIS outlet glaciers drain (Leverett, Russell, Ørkendalen and Isorlersuup glaciers). Incubations were set up at $2{ }^{\circ} \mathrm{C}$ in the dark, with and without $\mathrm{CO}_{2} / \mathrm{H}_{2}$ enrichment. We measured changes in methane and sulphate concentrations and assessed the temporal variability of bacterial and archaeal abundance and community structure in order to gain insight into anaerobic microbial activity. Details of the sample site, experimental set-up, gas and water sample analyses, qPCR set-up, sequencing protocol and sequence analysis are provided within Online Resource 1.

We observed an increase in methane within the $\mathrm{CO}_{2} / \mathrm{H}_{2}-$ amended incubations, from near the limit of quantification $5.14 \times 10^{-4} \pm 0.22 \times 10^{-4} \mu \mathrm{mol}$ on day 0 to $30.34 \times 10^{-4} \pm 5.99 \times 10^{-4} \mu \mathrm{mol}$ on day 147 (Fig. 1a). This increase was significant (two-tailed $t$ test; $t=7.27$; $p<0.01)$ and the mean production rate during this period was $4.29 \pm 1.02 \mathrm{pmol} \mathrm{g}^{-1} \mathrm{~d}^{-1}$ (wet weight), in line with rates measured from Russell Glacier subglacial sediments [6]. Between days 147 and 252, there was a significant decrease in methane to $12.60 \times 10^{-4} \pm 2.19 \times 10^{-4} \mu \mathrm{mol}$ (two-tailed $t$ test; $t=4.81 ; p<0.01$ ), followed by another increase to $23.23 \times 10^{-4} \pm 3.00 \times 10^{-4} \mu \mathrm{mol}$ by day 371 (two-tailed $t$ test; $t=4.97 ; p<0.01$; Fig. 1a). The decrease between days 147 and 252 was coincident with a significant depletion in sulphate from $1.49 \pm 1.29 \mu \mathrm{mol}$ to $0 \pm 0 \mu \mathrm{mol}$ (two-tailed $t$ test; $t=25.99 ; p<0.01$; Fig. $1 \mathrm{~b}$ ). We calculate that between days 147 and 252, methane oxidation occurred at rates of $4.22 \mathrm{pmol} \mathrm{g}^{-1} \mathrm{~d}^{-1}$ and sulphate reduction occurred at rates 1000 -fold greater, at $3.54 \mathrm{nmol} \mathrm{g}^{-1} \mathrm{~d}^{-1}$, assuming that sulphate was not depleted before day 252 . Within control incubations, methane increased minimally between days 60 and $251\left(\sim 2.2 \times 10^{-4} \mu \mathrm{mol}\right.$ increase; linear regression $R^{2}$ coefficient $\left.\left(\mathrm{LRR}^{2}\right) \geq 0.83 ; p<0.01\right)$. Methane

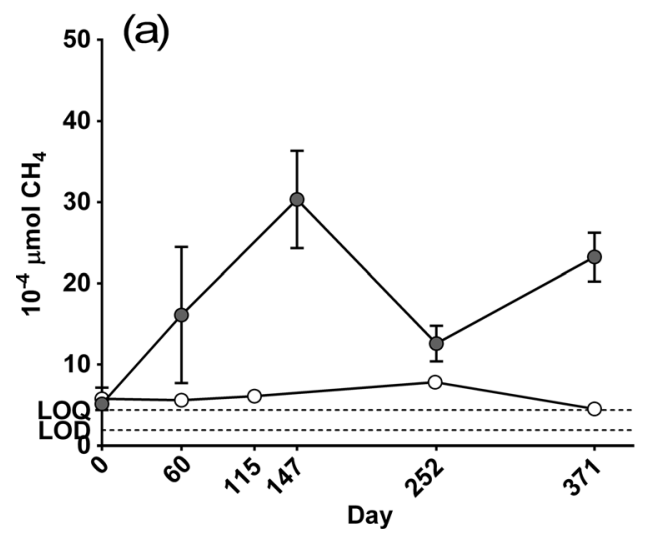

Fig. 1 Chemistry of incubations. a Methane abundance per incubation $\left(10^{-4} \mu \mathrm{mol}\right)$. b Sulphate abundance per incubation ( $\left.\mu \mathrm{mol}\right)$. Error bars show the standard deviations. Dashed lines indicate the limit of detection abundance measurements from control and $\mathrm{CO}_{2} / \mathrm{H}_{2}$ amended incubations were statistically different on days 60, 251/252 and 371 (two-tailed $t$ test; $t=3.64 ; p=0.01$ ). There was no significant difference between methane measured on day 0 under the two incubation conditions (twotailed $t$ test; $t=0.87 ; p=0.48$ ). Sulphate was found to decrease significantly between days 115 and 251 within the control set-up $\left(\mathrm{LRR}^{2}=0.93 ; p<0.01\right)$.

Bacterial and archaeal cell abundance decreased threefold during the $\mathrm{CO}_{2} / \mathrm{H}_{2}$-amended incubations from $2.61 \times 10^{5} \pm 0.96 \times 10^{5}$ cells per gram at day 0 to $7.67 \times 10^{4} \pm 1.20 \times 10^{4}$ cells per gram at day 371 . Catchall-calculated alpha diversity of $16 \mathrm{~S}$ rRNA gene amplicons was notably and significantly reduced during the $\mathrm{CO}_{2} / \mathrm{H}_{2}$-amended experiment, from $1307 \pm 65$ at the start of the experiment to $268 \pm 77$ at the end $\left(\mathrm{LRR}^{2}=0.78 ; p<0.01\right)$. No significant change in diversity was observed within the control incubations $\left(\mathrm{LRR}^{2}=0.27\right.$; $p=0.09$ ). The $\mathrm{CO}_{2} / \mathrm{H}_{2}$-amended communities were found to be highly dissimilar to the control incubation communities when a two-way analysis of similarity (ANOSIM) was performed, accounting for differences in sampling time $(R=0.83 ; p<0.01)$. Due to the reduction in cell abundance and diversity, and their ANOSIM-calculated uniqueness, we focus on the $\mathrm{CO}_{2} / \mathrm{H}_{2}$-amended communities herein.

$\mathrm{CO}_{2} / \mathrm{H}_{2}$-amended communities sampled at different time points were found to be dissimilar $($ GlobalR $=0.71$; $p<0.01)$. The greatest dissimilarities were found between the day 0 communities and the other communities $(R \geq 0.82$ ), while days 60,147 and 371 communities were found to be moderately similar to each other $(R \leq 0.44)$; however, due to a low number of samples, the results of these analyses were not statistically significant. SIMPER analysis highlighted 19 operational taxonomic units (sequence clusters with $\geq 97 \%$ similarity; OTU) that contributed towards $\geq 1 \%$ of the dissimilarities found between communities sampled at

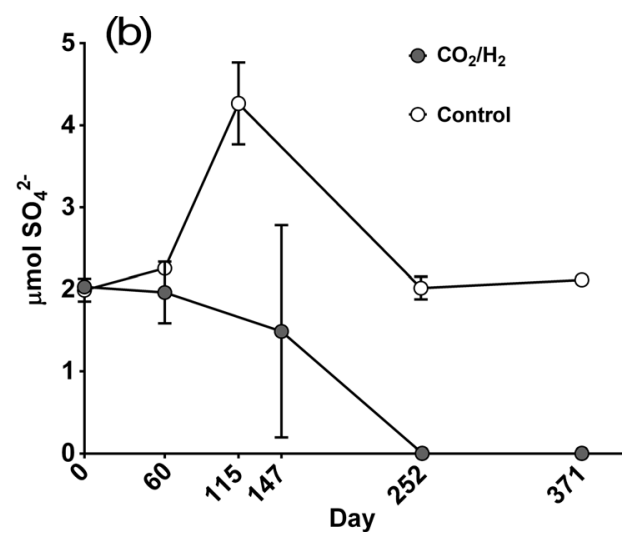

(LOD) and limit of quantification (LOQ) for methane analysis. The LOD for sulphate analysis was $0.52 \mu \mathrm{mol} \mathrm{L}{ }^{-1}$ or an absolute abundance of $0.0094 \mu \mathrm{mol}$ within each incubation 
different time points (Fig. 2). Of these OTU, four that were closely related to Desulfosporosinus meridiei of the Peptococcaceae family dominated the communities on day 371 (Fig. 2d). Desulfosporosinus are sulphate reducers that grow chemolithoautotrophically on hydrogen [9]. In total, 17 OTU that were closely related to $D$. meridiei were found within the day 371 sampled communities, accounting for $4.00 \times 10^{4} \pm 0.31 \times 10^{4}$ cells per gram, or $52 \%$ of the population. The establishment of these sulphate-reducing species, which correlated with the depletion of sulphate (Pearson's $r=-0.96 ; p=0.04$ ), is convincing of the potential for subglacially sourced microbes to reduce sulphate within delta sediments, consistent with previous studies from subglacial environments $[4,8]$, although the incubation bottle effect cannot be excluded.

The relative abundance of methane cycling organisms sequenced was low $(0.10 \pm 0.17 \%$; Online Resource 2$)$, contrary to previous studies of subglacial discharge samples $[2,5]$. Methanogen-related amplicons that were closely related to Methanomicrobiales (two OTU) and Methanosarcinales (five OTU), including three OTU that were most closely related to anaerobic methanotrophic archaea (ANME) organisms, known also to be involved in sulphate-driven anaerobic oxidation of methane (AOM) [10], were identified in the day 0 and day 60 communities, which were consistent with previous studies of subglacial environments [5, 7, 11, 12] (Online Resource 2). Aerobic methylotrophs belonging to Methylobacteriaceae (four OTU) and Methylocystaceae (one OTU) were additionally identified (Online Resource 2). No methane cycling-related amplicons were detected within the final day 371 incubation.

The results of our methane cycling analysis are inconclusive; however, they inspire several hypotheses that warrant further investigation. First, we suggest that viable sulphate reducers and hydrogenotrophic methanogens are exported to the river delta from subglacial environments. Under the $\mathrm{CO}_{2} /$ $\mathrm{H}_{2}$-amended experimental conditions, sulphate reducers thrive, while the concurrent loss of diversity and cell abundance suggests that a sizable portion of the original community is rendered unviable. Second, methane production is likely substrate limited, as it was only notably detected in incubations where hydrogenotrophic methanogenesis substrates were added. Based on the concurrent decrease in methane and sulphate concentrations, and the increasing relative abundance of $D$. meridiei, a sulphate-reducing bacterium, we propose that methanogens are out competed by sulphate-reducing bacteria, possibly as a result of the latter having a higher affinity to hydrogen [13]. Third, AOM by ANME species, which were identified within the incubations, although not on day 252 , coupled with sulphate-reducing bacteria [14] such as Desulfobulbaceae and Desulfobacteraceae [15], may explain the methane sink that was observed between days 147 and 252, and this process may similarly occur in subglacial environments. Decreased partial pressures of hydrogen and elevated partial pressures of methane during the first months of incubation may have stimulated reverse methanogenesis, which likely mediates AOM [16]. We hypothesise that once sulphate is depleted, net methanogenesis may resume. Freshwater flux from the GrIS is predicted to increase over the coming decades [17], which will likely increase biomass transport from the subglacial environment [2]. This study finds that subglacial microbiota are a dynamic community that have the potential to contribute to the biogeochemical cycling of delta ecosystems, and we therefore suggest that any ecological significance will increase as climate warming continues. (a)

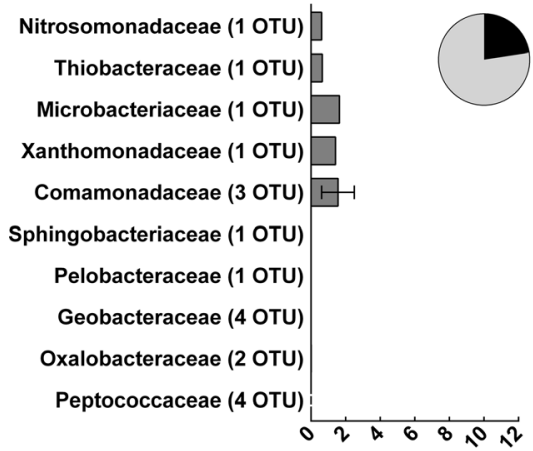

(b)

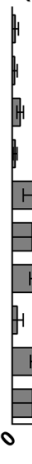

Fig. 2 Estimated absolute abundance of cells associated with OTU (19) that contributed towards $\geq 1 \%$ of the dissimilarities found between $\mathrm{CO}_{2} /$ $\mathrm{H}_{2}$-amended communities, within a $\mathrm{T} 1$; day 0 , b T2; day 60, c T3; day 147 and d T5; day 371 sampled $\mathrm{CO}_{2} / \mathrm{H}_{2}$-amended communities. Estimations were calculated using qPCR analyses of 16S rRNA gene copy numbers in combination with reference data of $16 \mathrm{~S}$ rRNA gene (c)

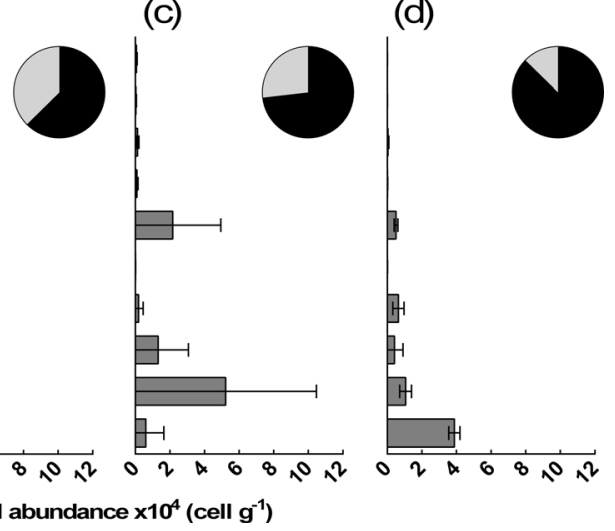

copy numbers per cell for each Greengenes OTU. Estimations are based on OTU grouped at the family level and the number of OTU associated with each family level group is displayed in parentheses. Error bars show the standard deviations. Inset pie charts depict the relative abundance of cells associated with these 19 OTU within each community, shown in black 
Acknowledgements This research was funded by Danish Research Council grants FNU 10-085274 to CSJ and CENPERM DNRF100. It has additionally been supported by a Czech Science Foundation grant GACR 15-17346Y to MS. We thank Pernille Stockmarr and Michael Petersen for the technical assistance.

\section{Compliance with Ethical Standards}

Conflict of Interest The authors declare that they have no conflict of interest.

Open Access This article is distributed under the terms of the Creative Commons Attribution 4.0 International License (http:// creativecommons.org/licenses/by/4.0/), which permits unrestricted use, distribution, and reproduction in any medium, provided you give appropriate credit to the original author(s) and the source, provide a link to the Creative Commons license, and indicate if changes were made.

\section{References}

1. Hasholt B, Mikkelsen AB, Nielsen MH, Larsen MAD (2012) Observations of runoff and sediment and dissolved loads from the Greenland ice sheet at Kangerlussuaq, West Greenland, 2007 to 2010. Z Geomorphol, Supplementary Issue 57:3-27. doi:10.1127/0372-8854/2012/S-00121

2. Cameron KA, Stibal M, Hawkings JR, Mikkelsen AB, Telling J, Kohler TJ, Gözdereliler E, Zarsky JD, Wadham JL, Jacobsen CS (2016) Meltwater export of prokaryotic cells from the Greenland ice sheet. Environ. Microbiol. doi:10.1111/1462-2920.13483

3. Boyd ES, Skidmore M, Mitchell AC, Bakermans C, Peters JW (2010) Methanogenesis in subglacial sediments. Environ. Microbiol. Rep. 2:685-692. doi:10.1111/j.1758-2229.2010.00162.x

4. Skidmore ML, Foght JM, Sharp MJ (2000) Microbial life beneath a high Arctic glacier. Appl. Environ. Microbiol. 66:3214-3220. doi:10.1128/aem.66.8.3214-3220.2000

5. Dieser M, Broemsen ELJE, Cameron KA, King GM, Achberger A, Choquette K, Hagedorn B, Sletten R, Junge K, Christner BC (2014) Molecular and biogeochemical evidence for methane cycling beneath the western margin of the Greenland ice sheet. ISME J 8: 2305-2316. doi:10.1038/ismej.2014.59

6. Wadham JL, Arndt S, Tulaczyk S, Stibal M, Tranter M, Telling J, Lis GP, Lawson E, Ridgwell A, Dubnick A, Sharp MJ, Anesio AM, Butler CEH (2012) Potential methane reservoirs beneath Antarctica. Nature 488:633-637. doi:10.1038/nature11374

7. Stibal M, Wadham JL, Lis GP, Telling J, Pancost RD, Dubnick A, Sharp MJ, Lawson EC, Butler CE, Hasan F (2012) Methanogenic potential of Arctic and Antarctic subglacial environments with contrasting organic carbon sources. Glob Change Biol 18:3332-3345. doi:10.1111/j.1365-2486.2012.02763.x
8. Wadham JL, Bottrell S, Tranter M, Raiswell R (2004) Stable isotope evidence for microbial sulphate reduction at the bed of a polythermal high Arctic glacier. Earth Planet. Sci. Lett. 219:341355. doi:10.1016/s0012-821x(03)00683-6

9. Pester M, Brambilla E, Alazard D, Rattei T, Weinmaier T, Han J, Lucas S, Lapidus A, Cheng J-F, Goodwin L, Pitluck S, Peters L, Ovchinnikova G, Teshima H, Detter JC, Han CS, Tapia R, Land ML, Hauser L, Kyrpides NC, Ivanova NN, Pagani I, Huntmann M, Wei C-L, Davenport KW, Daligault H, Chain PSG, Chen A, Mavromatis K, Markowitz V, Szeto E, Mikhailova N, Pati A, Wagner M, Woyke T, Ollivier B, Klenk H-P, Spring S, Loy A (2012) Complete genome sequences of Desulfosporosinus orientis DSM765(T), Desulfosporosinus youngiae DSM17734(T), Desulfosporosinus meridiei DSM13257(T), and Desulfosporosinus acidiphilus DSM22704(T). J. Bacteriol. 194:6300-6301. doi:10.1128/JB.01392-12

10. Lloyd KG, Alperin MJ, Teske A (2011) Environmental evidence for net methane production and oxidation in putative ANaerobic MEthanotrophic (ANME) archaea. Environ. Microbiol. 13:25482564. doi:10.1111/j.1462-2920.2011.02526.x

11. Stibal M, Hasan F, Wadham JL, Sharp MJ, Anesio AM (2012) Prokaryotic diversity in sediments beneath two polar glaciers with contrasting organic carbon substrates. Extremophiles 16:255-265. doi:10.1007/s00792-011-0426-8

12. Hamilton TL, Peters JW, Skidmore ML, Boyd ES (2013) Molecular evidence for an active endogenous microbiome beneath glacial ice. ISME J 7:1402-1412. doi:10.1038/ismej.2013.31

13. Oremland RS, Polcin S (1982) Methanogenesis and sulfate reduction: competitive and noncompetitive substrates in estuarine sediments. Appl. Environ. Microbiol. 44:1270-1276

14. Boetius A, Ravenschlag K, Schubert CJ, Rickert D, Widdel F, Gieseke A, Amann R, Jørgensen BB, Witte U, Pfannkuche O (2000) A marine microbial consortium apparently mediating anaerobic oxidation of methane. Nature 407:623-626. doi:10.1038/35036572

15. Pernthaler A, Dekas AE, Brown CT, Goffredi SK, Embaye T, Orphan VJ (2008) Diverse syntrophic partnerships from deep-sea methane vents revealed by direct cell capture and metagenomics. Proc. Natl. Acad. Sci. U. S. A. 105:7052-7057. doi:10.1073 /pnas.0711303105

16. Meulepas RJ, Jagersma CG, Zhang Y, Petrillo M, Cai H, Buisman CJ, Stams AJ, Lens PN (2010) Trace methane oxidation and the methane dependency of sulfate reduction in anaerobic granular sludge. FEMS Microbiol. Ecol. 72:261-271. doi:10.1111/j.15746941.2010.00849.x

17. Fettweis X, Franco B, Tedesco M, Van Angelen JH, Lenaerts JTM, Van den Broeke MR, Gallée H (2012) Estimating Greenland ice sheet surface mass balance contribution to future sea level rise using the regional atmospheric climate model MAR. Cryosphere 7:31013147. doi:10.5194/tc-7-469-2013 